\title{
The Rule of Law and Its Development: A Bird Eye View
}

\author{
Ram Krishna Timalsena, PhD \\ Executive Director/Founder Principal, \\ National Law College \\ Email: rktimalsena@nalc.edu.np
}

\begin{abstract}
The paper highlights the origin of rule of law and its development around the world in the context of present liberal democratic framework. The paper discusses rule of law from its international to national perspectives with special emphasis on supremacy of law. Rule of law has not been analyzed from Anglo-American purview in the article, but this article also discusses on German and Japanese perspectives. It takes notes on latest constitutional development of Nepal as well.
\end{abstract}

Key Words: Rule of law, rechtsstaat, thin approach, substantive approach, morality of law

\section{Introduction}

Rule of law is the umbrella term in $21^{\text {st }}$ century democracy. It is connected to every aspect of public policy, governance and law. It is also closely tied up with human freedoms, equality and justice. Economic prosperity to maintaining human dignity is the issue of rule of law. As the rule of people is called democracy the rule of law can be termed as nomocracy (from the Greek nomos (law) and kratos (power or rule).

Although the concept was originated in the ancient Hindu Philosophy the modern specific deliberation on the topic is occidental. Even in the west, the concept was discussed in the yore by various political thinkers. Aristotle wrote "Law should govern". Rule of law implies that every citizen is subject to the law. It stands in contrast to the idea that the ruler is above the law" (jusprudentia.com). Likewise in ancient Rome Cicero advocated the higher position of law by saying "We are all servants of the laws in order that we may be free" (Tamanaha, 2004). In England, It was the Bracton who wrote "that the King ought not to be under any man but under God and the law" (quod Rex non debedesse sub homine, sed sub Deoetlege ). It was nothing but rule of law in modern parlance. Samuel Rutherford was the first modern authors to give the principle theoretical foundations. He reversed the traditional concept of "king is the law" to "the law is the king" in 1644 (Martin, 2014). Likewise, famous political thinker John Locke also discussed the concept of rule of law in his Second Treatise of Civil Government in 1689. John Locke emphasized the importance of governance through "established standing Laws, promulgated and known to the People". Locke distinguished the rule of settled standing laws from arbitrary decrees. The principle was also deliberated by notable scholar Montesquieu in The Spirit of the Laws in 1748. Montesquieu's work on the Rule of Law is best known in connection with his theory of separation of powersparticularly the separation of judicial power from executive and legislative authority. The judiciary has to be able to do its work as the mouthpiece of the laws without being distracted from fresh decisions made in the course of its considerations by legislators and policy-makers. For the first time the phrase "rule of law" was included in Samuel Johnson's Dictionary in the year 1755.

In the American context, Thomas Paine, in his famous pamphlet "Common Sense" wrote that "in America, the law is king. He emphasized that 'in a free country the law ought to be king; and there ought to be no other.' From the constitutional documents point of view we can cite the Massachusetts Constitution 1780 which clearly stipulated "a government of laws and not of men." It 
was John Adams who drafted these words. All these concepts were the foundational concept of rule of law.

\section{Systematic Development}

As we traced the concept of the rule of law was very old. Its systematic development is gradually taking place. Its main focus is on supremacy of regular constitutional and legal power as opposed to arbitrary power. Albert Venn Dicey, (A.V. Dicey) was a first British Law Professor and constitutional theorist who popularized the phrase "rule of law", although its use goes back to the 17th century (Meyerson, 2004). For Dicey rule of law means at least the following three things:

- Supremacy of Law: Under this concept law alone is supreme to determine right and wrong and to settle any dispute. It can only check arbitrary power or wide discretionary power. It also includes that a man can be punished by rule of law, and by nothing else. Similarly it focuses on that every government is a subject of the Rule of Law, rather than the law being a subject of the Government.

- Equality before Law: It means everyone is equal before the law or equal subjection of all classes to the ordinary law. All citizens are subject to one and the same law. Protection of law is equally important to this perspective. There should not be extraordinary tribunals or special courts to deal with cases of Government and its.

- Constitution is the consequence not source: It means rights such as right to personal liberty, speech, assembly etc.) are the result of judicial decisions in England. The rights are a result of court judgments rather than from being protected in the Constitution. The Constitution is a consequence and not the source of the liberties of the individuals. Thus, Courts are the guarantors of the rights. Rights would be secured more adequately if they were enforceable in courts rather than just being written in the Constitutional text. Only incorporation in a written constitution is of no use in the absence of effective enforcement of these rights.

Lon L. Fuller, in his book The Morality of Law (1964) articulated eight principles of what he called "the inner morality of law"- principles requiring that laws be general, public, prospective, coherent, clear, stable, and practicable - and he argued that these were indispensable to law-making. This concept is very clearly connected to the quality and process of making law. He termed it as inner morality of law (Jeremy, 2016). In recent years 'Rule of Law' is seen more as a concept of rights of citizens. It is a fundamental component of liberal political tradition. By observing all past literature of rule of law the Secretary General of UN has defined rule of law as follows: (un.org)

"A principle of governance in which all persons, institutions and entities, public and private, including the State itself, are accountable to the laws that are publicly promulgated, equally enforced and independently adjudicated, which are consistent with the international human rights norms and standards. It requires, as well, measures to ensure adherence to the principles of supremacy of law, equality before the law, accountability to the law, fairness in the application of the law, separation of powers, participation in decision making, legal certainty, avoidance of arbitrariness and procedural and legal transparency." This definition touches upon the vast scope of the rule of law. World Justice Project has identified the following four principles as regards to rule of law (worldjusticeproject.org):

- The government and its officials are accountable under law.

- The laws are clear, publicized, stable and fair, and protect fundamental rights, including the security of persons and property. 
- The process by which the laws are enacted, administered and enforced is accessible, fair, and efficient.

- Access to justice is provided by competent, independent, and ethical adjudicators, attorneys or representative, and judicial officers who are of sufficient number, have adequate resources, and reflect the makeup of the communities they serve.

Most legal theorists believe that the rule of law has purely formal characteristics, meaning that the law must be publicly declared, with prospective application, and possess the characteristics of generality, equality, and certainty, but there are no requirements with regard to the content of the law. Others, including a few legal theorists, believe that the rule of law necessarily entails protection of individual rights (Current Legal Problems, Vol 55). Among modern legal theorists, most views on this subject fall into three general categories (Tommasoli, 2012)

- the formal (or "thin") approach,

- the substantive (or "thick") approach, and

- the functional approach.

Formalist definitions do not make a judgment about the "justness" of law itself, but it defines specific procedural attributes that a legal framework must have in order to be in compliance with the rule of law. Under this approach properly made law is supposed to be just. No institution or individual should question its justness. Substantive conceptions go beyond this and include certain substantive rights that are said to be based on, or derived from, the rule of law. It supports basic rights of individuals should be protected by law. This conception is searching legitimacy of enacted law. Under this conception rule of law seeks rule of just law.

The third conception is functional concept that says, a society in which government officers have a great deal of discretion has a low degree of "rule of law", whereas a society in which government officers have little discretion has a high degree of "rule of law". It tries to limit the discretionary power or authority of public servant. There is also a distinction between rule of law and rule by law. According to Professor Li Shuguang: "The difference is that, under the rule of law, the law is preeminent and can be serve as a check against the abuse of power. Under rule by law, the law is a mere tool for a government that suppresses in a legalistic fashion" (nnamdiebo.com ).

\section{Rule of law and German Rechtsstaat}

There are some differences between the rule of law as developed to common law based countries and legal state as practiced by many civil aw based countries. The former focuses on the role of court whereas the later emphasizes scholar developed notion of legal state. Rule of Law corresponds to the German Rechtsstaat, which meansall modern legal systems in which public powers have a legal source and form are "legal states" in a merely formal meaning of the "rule of law". In a legal state the following matters are important (escapistmagazine.com):

- Transparency of state acts and the requirement of providing a reasoning for all state acts

- Review of state decisions and state acts by independent organs, including an appeal process

- Hierarchy of laws, requirement of clarity and definiteness

- Reliability of state actions, protection of past dispositions made in good faith against later state actions, prohibition of retroactivity

- Principle of the proportionality of state action 
German concept of Rechtsstaat is different with British concept of rule of law. Despite a superficial resemblance to the English Rule of Law, with its emphasis on the notion of administration by law, the Rechtsstaat is very different. The Rechtsstaat, when combined with the legal positivism that regards the law as an order of the ruling authority, represents no more than the self-restraint of the state power (Bono, n.d., Vol 72.229).

The major distinction between the Rule of Law underlying traditional western constitutionalism and the Rechtsstaat or legal state of German and Japanese origin can be analyzed from its focus. The Western- Rule of Law holds that powers and rights vest naturally in individuals, and that government is limited in its power to infringe upon these rights. On the contrary, the RechRechtsstaat, a more hierarchical tradition, holds that all powers and rights naturally vest in government, which then allocates rights and powers to its citizens. Rechtsstaat does not recognize any individual rights as fundamental; government and not nature is the source of individual rights. This distinction is generally discussed in the Japanese academic world of jurisprudence. This is because the Meiji Constitution of 1889 surely stood on the German concept of the Rechtsstaat (Urabe, n.d.).

\section{Conclusion}

In Nepal the Constitution of 2015 clearly mandates the concept of rule of law through its perambulatory provisions and other provisions regarding fundamental rights. We are now following British pattern of rule of law despite our written and supreme law of the land. We do have power of judicial review that rejects the idea of ordinary law. The Constitution is higher law of the land. Our constitution is not the result of court judgment as Dicey saw it in England. We are very close to US model rule of law concept from constitutional point of view.

Despite all legal and constitutional arrangements of rule of law there are some challenges to the implementation of the concept in Nepal that can be summarized as follows:

- The foremost challenge is a widespread impunity that is impeding law enforcement, fueling a breakdown in law and order, and enabling crime and violence to proliferate.

- A second major challenge is limited access to justice, especially for vulnerable and marginalized populations, and the historic exclusion of many from representation in justice institutions and the legal profession on grounds of gender, ethnicity, and caste.

- The third challenge is the need for independence and professionalism to enable the justice system to serve as a check on abuse and a protector of rights and constitutional norms.

\section{References}

Bentham, J. (1782). Of Laws in General. Ed. H.L.A. Hart, 1970. London: Athlone Press.

Broom, H. (2001).A Selection of Legal Maxims Classified and Illustrated, , (London: Sweet \& Maxwell Limited

Dworkin, R. (1986). Law's Empire. Cambridge MA: Harvard University Press.

Finnis, J. (1980), Natural Law and Natural Rights, Oxford: Clarendon Press; 2nd ed., with same pagination and a Postscript, 2011.

Justice. (2016). World justice. Retrieved from https://worldjusticeproject.org/our-work/wjp-rule-lawindex/wjp-rule-law-index-2017\%E2\%80\%932018

Martin, R.D. (2014). Was the American revolution sinful? Retrieved from http://rodmartin.org/american-revolution-sinful/ 
5 | Journal of APF Command and Staff College

Meyerson, D. (2004). The rule of law and the separation of powers. Macquarie Law Journal,(4)

Quod Rex non debedesse sub homine, sed sub Deoetlege (2018). Retrived from http://www.duhaime.org/LegalDictionary/R/RexDebetEsseSubLegeQuiaLexFacitRegem.asp $\mathrm{x}$

Ricardo G. (n. d.). The significance of the rule of law and its implications for the European Union and the United States University of Pittsburgh Law Review (72) 229

Rule of Law. (2014). Jusprudentia. Retrieved from https://www.un.org/ruleoflaw/what-is-the-rule-oflaw/jusprudentia.com/rule-of-law-2/

Rule of Law. (2015). Plato Standford. Retrieved from

https://plato.stanford.edu/archives/fall2016/entries/rule-of-law/

Tamanaha, B.Z. (2004). On the rule of law: History, politics, theory. United Kingdom: Cambridge University Press.

Tommasoli, M. (2012). Rule of law and democracy: Addressing the gap between policies and practices (49) 4 UN Chronicle.

Urabe, N. Rule of Law and due process: A comparative view of the United States and Japan, law and contemporary problems (vol. 53: no. i)

Waldron, Jeremy. (2016). "The Rule of Law”, The Stanford Encyclopedia of Philosophy (Fall 2016 Edition), Edward N. Zalta (ed.), Retrieved from

Waluchow, W.J. (1994). Inclusive Legal Positivism. Oxford: Clarendon Press

Washington, DC: Regnery. ( 1964) The Theme is Liberty: Religion, Politics and the American Tradition. London:Elit Media. 